\title{
PREGNANCY TERMINATIONS IN RUSSIA ACCORDING TO OFFICIAL STATISTICS
}

Victoria I. SAKEVICH, Cand. Sci. (Econ.), Senior Researcher, Institute of Demography named after A.G. Vishnevsky, National Research University Higher School of Economics (vsakevich@hse.ru); Boris P. DENISOV, Cand. Sci. (Econ.), First Category Engineer, Faculty of Economics, Lomonosov Moscow State University (denisov@demography.ru); Svetlana Yu. NIKITINA, Cand. Sci. (Econ.), Director, Department of Population and Healthcare Statistics, Rosstat (nikitina_s@gks.ru). All - Moscow, Russia.

Acknowledgements. The article is based on the research implemented in the framework of the Basic Research Program at the National Research University Higher School of Economics.

Abstract. For a long period, Russia was among the world leaders in the prevalence of abortions, which was a serious public health problem. In the post-Soviet years, the induced abortion rates have been steadily declining, and today more than half of Russian women of reproductive age live in regions characterized by a low abortion rate even by European standards. The article describes in detail the evolution of statistical accounting for abortions in Russia. The most recent changes in registration forms for the first time produced a possibility to evaluate the contribution of non-governmental clinics to the total number of abortions and to distinguish between induced and spontaneous abortions, which have completely different causes. On the basis of official state statistics that are not routinely published by Rosstat, we conclude about a significant increase in the effectiveness of birth control in modern Russia. From the main instrument of regulation of the number of children and the timing of their births by families, abortion has turned into an emergency, "firefighting" measure. Analysis of regional differences showed that in some regions located mainly in the north and east of the country, the problem of abortion has not lost its relevance. Every sixth Russian woman of reproductive age live in regions with a relatively high level of induced abortions.

Keywords: reproductive health $\bullet$ reproductive behavior $\bullet$ birth control $\bullet$ abortion $\bullet$ family planning

\section{DOI: $10.31857 / S 013216250016791-3$}

This article is a translation of: Сакевич В.И., Денисов Б.П., Никитина С.Ю. Прерывания беременности в России по данным официальной статистики // Sotsiologicheskie Issledovaniia. 2021. No 9: 43-53. DOI: 10.31857/S013216250014958-6

Abortion in Russia was probably the main tool of the demographic transition in fertility. Russia was the first country in the world (in 1920) to legalise the right to abortion on request. Women, with no other means at their disposal to postpone or avoid having a baby, were forced to terminate their pregnancies. In response to popular demand, an "abortion industry" emerged that also survived the period of abortion prohibition. In 1964, Russia recorded a record 5.6 million aborted pregnancies, or 169 abortions per 1,000 women aged 15 to 49 . Then the abortion rate decreased slightly, but was still very high [Demographic modernisation..., 2006: 195-246].

The past 30 years have seen important shifts in the structure of methods by which the number and timing of children is managed at the individual and family level. Nevertheless, the problem of ineffective birth control in Russia continues to attract the attention of politicians and the public. There is a lot of information buzz around the topic of abortion and family planning; the public debate and even the scientific literature often use unreliable data, dubious sources of information, and sometimes the facts are deliberately distorted for one purpose or 
another. For example, proponents of the religious view of abortion ("the embryo is a separate person and abortion is murder") or "statists" who view abortion as a reserve for fertility growth, with little understanding of how abortion accounting works, tend to exaggerate the severity of the problem. Both tend to call on the authorities to tighten abortion laws ${ }^{1}$.

In addition to the long history of the legal right to terminate a pregnancy, Russia also has a rather long history of abortions being recorded by the statistical authorities. In 1955, abortion was re-legalised, and by the mid-1960s abortion was registered again (Avdeev et al., 1995: 52). It has since become commonplace to criticise the completeness of domestic abortion statistics. During Soviet times, the Soviet tradition of manipulating statistics for ideological reasons was the main argument for such criticism, and in the post-Soviet years, the rapid decline in abortions is questioned by many. There is an opinion that in modern Russia a part of abortions has "moved" to private clinics and has allegedly fallen off the statistical radar [Starodubov, Sukhanova, 2012: 187]. We do not agree with this. A whole series of sample surveys of the population in the post-Soviet years showed the same level of abortion prevalence as the official statistics [Denisov, Sakevich, 2014: 148-149]. Some underreporting of abortions in the private sector is likely to occur, but in an environment where abortion is absolutely legal and its concealment by health facilities is punishable, such underreporting cannot be statistically visible. Russia is in a relatively small group of countries with official statistics on abortion, and this is our real advantage - in most countries the number of abortions is not reliably known and we have to rely on estimates.

The article describes the statistical system for pregnancy termination in Russia, provides a brief history of its changes in recent decades and assesses the comparability of official data over the years. The current abortion situation is analysed on the basis of state statistics, including a regional perspective. Since 2018 , the updated abortion registers have provided valuable information that was not available in previous years, such as answering the question of how non-governmental organisations contribute to the total number of abortions and separating induced abortions from spontaneous abortions, which have other causes and require a completely different response.

Data. From 1956 to 1991, the procedure for statistical registration of abortions remained virtually unchanged [David, Popov, 1999: 242]. Both abortions performed in the health facility and abortions initiated or started outside the health facility ("out-of-hospital") were included in the report of the health facility. The latter consisted of spontaneous abortions (miscarriages) and criminal interventions, with the ratio has been, and remains unknown. The inclusion of miscarriages was partly due to the nature of the socialist economy, where future numbers of "abortion beds" were planned on the basis of the report, irrespective of the nature of the abortion (Avdeev et al., 1995: 57). It is also worth noting that abortion statistics during this period were classified "for official use" and were not published until the late 1980s.

In 1991, a new form for registering abortions in ministry and departmental clinics was introduced, which involved the recording of several categories of terminated pregnancies, 44 partly in accordance with the ICD9th revision. The information collected was supplemented by the identification of several age groups of women and gestational age. In 1992, after the collapse of the USSR, this form ("Form 13") was reproduced in a Resolution of the State Committee of Statistics of the Russian Federation for public health institutions in Russia.

Form 13 abortions were - and indeed still are - divided into the following groups: spontaneous abortions, induced legal abortions (later "medical legal"), induced legal abortions for medical reasons, induced abortions for social reasons, induced criminal abortions (later

${ }^{1}$ Demidov A. The Russian Orthodox Church has spoken out in favour of the idea of including abortions in mortality statistics // Gazeta.ru. 2021. 20 February. URL: https://www.gazeta.ru/social/news/2021/02/20/n_15646544. shtml (accessed on 25/06/2021); Shipacheva D. "Woman is so programmed that she has to give birth for someone": What representatives of the Ministry of Health and the State Duma talked about at the discussion on the problems of abortion in Russia // Takie dela. 2020. 18 December. URL: https://takiedela.ru/news/2020/12/18/reshitproblemu-abortov/ (accessed on 25/06/2021). See also: [Zhukov, 2018; Ryazantsev et al., 2019]. 
"other - criminal"), and unspecified abortions. Before 2009, mini-abortions (i.e. early abortions performed by vacuum-aspiration) were also counted ${ }^{2}$.

Induced legal or medical legal abortions are abortions at a woman's request up to 12 weeks of pregnancy. Together with abortions for medical and social reasons, they form a group of "medical" abortions. Spontaneous abortions (or miscarriages) include abortions that began spontaneously but occurred or ended in a health facility. Abortion is considered to be criminal if it is detected that the pregnant woman herself or others have intervened outside the hospital to terminate the pregnancy. In other countries with established abortion records, the number of induced abortions (without miscarriages and illegal abortions) is usually published, i.e. the Russian figure is overstated compared to other countries. Form 13 is now used to record pregnancy terminations in organisations that report to the Ministry of Health. For other organisations - non-state-owned, as well as medical units of other ministries and departments a different form of federal statistical observation ("Form 1-zdrav") is used; data on abortions in this form are not submitted to the Ministry of Health, but to the territorial divisions of Rosstat (Russian Federal State Statistics Service). Rosstat summarises information from all sources and publishes consolidated data on terminated pregnancies.

Throughout the post-Soviet period, these statistical forms have been adjusted several times, but until recently the changes were not very significant. Since 1999, with the adoption of the ICD10th revision, abortions have been referred to as pregnancy terminations ${ }^{3}$, but the abortion categories have remained largely unchanged. After the new definition of live birth was adopted, the gestational age at which abortion is allowed decreased from 27 full weeks to 21 full weeks, but there were relatively few such late-term abortions ${ }^{4}$, so the statistics were not greatly affected.

A more notable step in the reform of the Form 13 system was the broadening of the criteria for spontaneous abortions, with the addition of an ICD-10 heading ("other abnormal products of conception") in 2012. This was done to emphasize the high importance of pregnancy failure as an important reproductive and demographic problem in the context of worsening, according to some authors, reproductive health of Russian women and the threat of depopulation in the country [Starodubov, Sukhanova, 2012; Sukhanova, 2013]. As a result, the number and proportion of spontaneous abortions has increased significantly. In one year, from 2011 to 2012, the number of spontaneous abortions in clinics of the Ministry of Health went up from 176,600 to 222,900 (by $26 \%$ ), including those before 12 weeks from 147,200 to 199,000 (by 35\%).

In 2016, the Ministry of Health made even more radical changes to Form 13. Pregnancy terminations became "pregnancies with abortive outcome" and the list of ICD-10 headings was expanded to include: ectopic pregnancies, hydatidiform mole and abortion failure (codes O00-O07 instead of 002-006 until 2016). The updated Form 13 has only been in force for a year; inconsistencies seem to have become apparent in the 2016 report. While between 2015 and 2014 the total number of terminated pregnancies declined by almost $9 \%$ (and the average rate of decline over the previous decade was 6\%), between 2016 and 2015 it declined by only $1.4 \%$. Since 2017 , the Form 13 has all the headings as a separate line, enabling the necessary categories of abortions to be highlighted, as was the case before 2016.

The age distribution of aborted pregnancies should be mentioned separately. From 1991 to 1995, the Form 13 records were kept by aggregated age groups of women who had terminated

2 Mini-abortions were permitted in 1987. (Order of the USSR Ministry of Health No. 757 of 05/06/1987), although, according to some evidence, it had been practiced since the early 1980s [Avdeev, 2011].

3 We use "pregnancy terminations" and "abortions" as synonyms. Abortions include both induced and spontaneous abortions.

${ }^{4}$ In 2011, on the eve of the transition to the new birth criteria, the Ministry of Health recorded 16,300 pregnancy terminations between 22 and 27 weeks of pregnancy, of which around $60 \%$ were miscarriages, which have been classified as super-early as of 2012. The share of abortions at 22-27 weeks in 2011 was $1.65 \%$ of all abortions in the Ministry of Health system. 
a pregnancy: under 15, 15-19, 20-34, 35 and over. As of 1996, the Ministry of Health has been allocating standard five-year age groups. However, in 2016, for unknown reasons, the five-year grouping was eliminated and the age distribution took the following form: under 14, 15-17, $18-44,45-49,50$ and over. Since one age group (18-44) accounts for $98 \%$ of all abortions, the new age division does not make analytical sense.

As for Form 1-zdrav ${ }^{5}$, this has changed little until recently, although, unlike Form 13, it contained a sparse set of information - the total number of abortions and the number of miniabortions. After 2010, individual categories of pregnancy terminations were identified in the accounting form, but by no means all, and the criteria for selecting these categories are unclear - either only medical but no spontaneous ones, or also spontaneous but only in late gestation. In fact, only the total number of aborted pregnancies could be used for analysis. From 1991 to 2007, Rosstat worked out the total number of abortions by aggregated age groups, and from 2008 to 2015 - by five-year age groups.

Significant changes were made to the content of Form 1-zdrav in 2016, when the list of "pregnancies with abortive outcome" was expanded as in Form 13 (codes 000-007 instead of 003-006 according to ICD-106). This form 1-zdrav was valid during 2016 and 2017, and the reports for those years are not comparable with other years. We estimate that the total number of abortions in these years was $8-10 \%$ higher than in previous years. For this reason, the Rosstat statistics on aborted pregnancies for 2016-2017 have to be excluded from the analysis. Starting with the 2018 report, the accounting of pregnancy terminations outside the Ministry of Health has changed again and for the first time is as detailed as that of the Ministry of Health. The Rosstat data on the number of abortions is not only again suitable for studying the dynamics, but for the first time also contains information on the distribution of abortions by headings in non-governmental medical institutions. Finally, it has become possible to distinguish between induced abortion and spontaneous abortion, which have very different justifications and reasons. The only regret is that the previous breakdown by age has not been restored.

Thus, at present, the government statistics on pregnancy terminations that Rosstat develops are made up of three components. The main source of data is the Ministry of Health, which records aborted pregnancies in its subordinate organisations (83.7\% of all abortions in 2019, $92-94 \%$ in the 1990s). The contribution of the non-governmental health sector is significantly lower (14.4\% in 2019); the share of abortions performed in organisations belonging to bodies other than the Ministry of Health is even lower (less than $2 \%$ in 2019). In this paper, we rely on Rosstat statistics as the most complete.

Trends in the prevalence of pregnancy termination. There has been a steady decline in the abortion rate in Russia over the last thirty years; this trend has never been interrupted. According to Rosstat data, the total number of pregnancy terminations (including miscarriages and abortions for medical and social reasons) decreased from 3.5 million to 622,000 in the post-Soviet period (1992-2019), or per 1000 women aged 15-49 years from 94.7 to 18.0 (see Table 1), i.e. by a factor of 5.3, though it should be noted that in 2019 , the definition of spontaneous abortion was different and the country's territory had widened by this time in comparison with 1992. The cumulative abortion rate, which can be calculated up to 2015, also shows a significant drop in the abortion rate: in the early 1990s, there were on average more than three terminated pregnancies per woman, while in 2015 it was 0.78 .

The abortion rate (per 1,000 women of reproductive age), calculated using the standard methodology, i.e. excluding spontaneous abortions, shows an almost eightfold decrease over these years: from 89.0 to 11.3. It is the latter figure that should be used for comparisons with other countries.

\footnotetext{
${ }^{5}$ Hereinafter, we will only talk about the seventh section of this form, dealing with abortion.

${ }^{6}$ A broader definition of spontaneous abortion was introduced for the Ministry of Health organisations in 2012 and for the rest in 2016.
} 
Pregnancy terminations in Russia, 1992-2019

\begin{tabular}{c|c|c|c|c|c}
\hline \multirow{2}{*}{ Year } & \multicolumn{2}{|c|}{ Pregnancy terminations (ths.) } & \multicolumn{2}{|c|}{ Pregnancy terminations* per } & $\begin{array}{c}\text { Total abortion } \\
\text { rate* }\end{array}$ \\
\cline { 2 - 5 } & total* & $\begin{array}{c}\text { including } \\
\text { spontaneous** }\end{array}$ & $\begin{array}{c}1000 \text { women } \\
\text { aged 15-49 years }\end{array}$ & 100 live births & \\
\hline 1992 & 3436.7 & $\mathrm{n} / \mathrm{a}$ & 94.7 & 216 & 3.24 \\
1995 & 2766.4 & $\mathrm{n} / \mathrm{a}$ & 72.8 & 203 & 2.62 \\
2000 & 2138.8 & $\mathrm{n} / \mathrm{a}$ & 54.2 & 169 & 2.00 \\
2005 & 1675.7 & $\mathrm{n} / \mathrm{a}$ & 42.7 & 117 & 1.51 \\
2010 & 1186.1 & $\mathrm{n} / \mathrm{a}$ & 31.7 & 66 & 1.07 \\
$2015^{* * *}$ & 848.2 & $\mathrm{n} / \mathrm{a}$ & 23.8 & 44 & 0.78 \\
2018 & 661.0 & 243.4 & 19.0 & 41 & $\mathrm{n} / \mathrm{a}$ \\
2019 & 621.7 & 232.3 & 18.0 & 42 & $\mathrm{n} / \mathrm{a}$ \\
\hline
\end{tabular}

Notes. *Codes according to ICD-10: for organisations of the Ministry of Health of Russia: O03O06 in 1992, 1995, 2000, 2005 and 2010, O02-O06 in 2015, 2018 and 2019; for organizations outside the Ministry of Health of Russia:

O03-O06 in 1992, 1995, 2000, 2005, 2010 and 2015, O02-O06 in 2018 and 2019. **Codes according to ICD-10:

O02-O03. *** As of 2015 including Crimea and Sevastopol.

Source: Calculated from Rosstat data.

An important characteristic of the abortion situation is also the ratio of abortions to births, which shows what proportion of pregnancies do not end in childbirth. In 2019, government statistics recorded 42 aborted pregnancies per 100 births, which means that around 30 per cent of pregnancies ended in abortion. Until 2007, for several decades, the annual number of abortions in Russia exceeded the number of births; in some years the ratio was over 250 abortions per 100 births, i.e. only one third of pregnancies ended in live births. Today, the effectiveness of birth control has improved considerably - there has been a convergence between the number of pregnancies and the number of births.

The multiple reductions in abortion rates have changed the position of our country compared to other developed countries. Not so long ago, Russia was among the leaders in the prevalence of abortion among countries with liberal abortion laws, but the gap has now been largely closed. In comparison, the induced abortion rate in Sweden is 16.9 per 1,000 women aged 15-49 (2017), France - 15.7 (2019), Estonia - 13.2 (2019), Denmark - 11.2 (2017), Norway - 10.6 (2017) and Germany - $5.8(2019)^{7}$.

Let's take a closer look at the situation in 2019 . The majority $(56.2 \%)$ of pregnancy terminations in organisations of all forms of ownership are "medical legal" abortions, i.e. abortions at a woman's request up to 12 weeks of pregnancy. Spontaneous abortions or miscarriages are the second largest contributors (37.4\% in 2019). The increase in the miscarriage rate was due both to changes in the reporting form and to a rapid decline in the number and proportion of induced abortions. Abortions for medical reasons (including social reasons) and unspecified

${ }^{7}$ Induced Abortions in the Nordic Countries 2019 // Finnish Institute for Health and Welfare. URL: https://thl.fi/en/web/thlfi-en/statistics/statistics-by-topic/sexual-and-reproductive-health/abortions/inducedabortions-in-the-nordic-countries; Abortions: Number of Induced Abortions and Annual Indicators since 1976 // INED. URL: https://www.ined.fr/en/everything_about_population/data/france/abortion-contraception/abortions/; Statistics Estonia: Statistical Database. URL: https://andmed.stat.ee/en/stat; Abortions: Abortions by Age of the Women and Quota // Statistisches Bundesamt. URL: https://www.destatis.de/EN/Themes/ Society-Environment/Health/Abortions/Tables/age.html (accessed on 20/04/2021). 
520.1 ths.

89.4 ths.

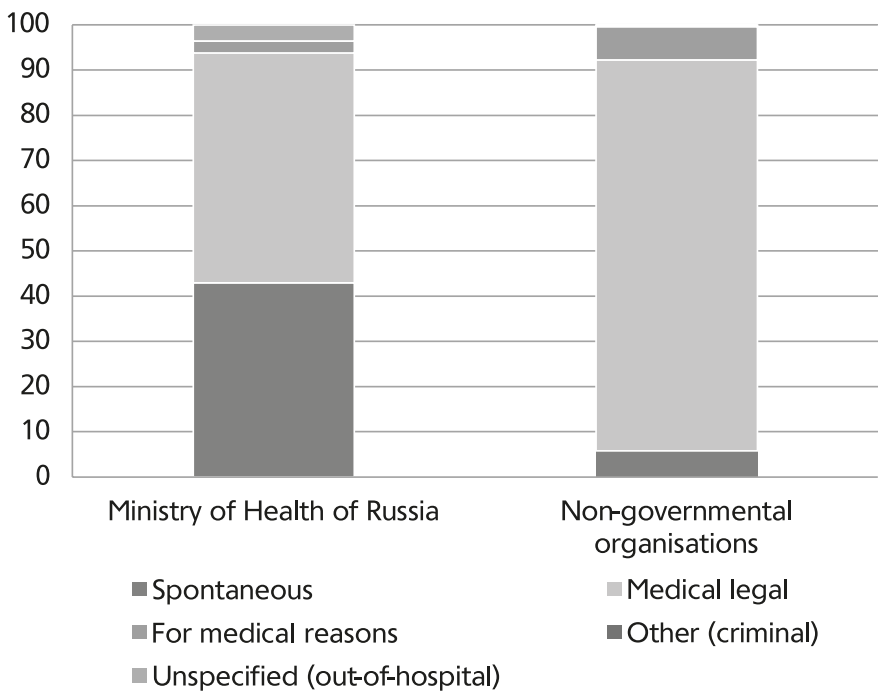

Fig. Structure of registered abortions in the organisations of the system of the Ministry of Health of Russia and in non-governmental organisations, 2019 (\%)

Source: Calculated on the basis of data from the Ministry of Health of Russia and Rosstat.

abortions each account for approximately three per cent of the total number of abortions, while criminal abortions account for a very small percentage ( 0.1 per cent) (a total of 352 criminal abortions were registered in 2019).

The contribution of different types of abortion in government and non-governmental medical organisations varies. In cases of miscarriage, women are more likely to be taken to government institutions, so the vast majority (96\%) of spontaneous abortions take place in institutions of the Ministry of Health. In the clinics of the Ministry of Health system, the share of spontaneous abortions among all abortions in 2019 was $42.9 \%$, while in private clinics the share of spontaneous abortions did not reach $6 \%$ (see Figure). There are almost no late-term abortions in non-public facilities, which is to be expected, since clinics with specialised (including resuscitation) medical facilities are entitled to perform such abortions.

At the same time, the safest method for terminating a pregnancy - medication abortion - is much more widely used in private clinics than in public ones. In $2019,72 \%$ of induced abortions in non-governmental organisations were performed using the medication method, while about $34 \%$ were performed in clinics of the Ministry of Health. Here lies some reserve for women's reproductive health.

The updated form allows for a more accurate assessment of the contribution of the nonpublic sector to the total number of abortions. If miscarriages are excluded, the share of nongovernmental organisations rises from $14.4 \%$ (as mentioned above) to $21.6 \%$; this means that at least one in five induced abortions in the country is performed in a private clinic.

Regional differences in the prevalence of pregnancy termination. The Russian average masks significant regional differences. Abortion rates tend to increase from west to east and from south to north. In 2019, the difference between the minimum and maximum figures - in the Republic of Ingushetia and the Jewish Autonomous Region - exceeded six times. The coefficient of variation based on the abortion rate shows considerable regional heterogeneity (see Table 2). The country is more homogeneous in terms of fertility rates than in terms of abortion rates. 
Table 2

Characteristics of regional* variation in abortion rates per 1,000 women aged 15-49 years, 2012-2015 and 2018-2019

\begin{tabular}{l|c|c|c|c|c|c}
\hline & 2012 & 2013 & 2014 & 2015 & 2018 & 2019 \\
\hline Minimum & 9.7 & 10.1 & 8.3 & 8.0 & 6.1 & 6.0 \\
Maximum & 58.4 & 55.6 & 53.0 & 47.2 & 37.7 & 37.0 \\
Unweighted arithmetic mean & 33.5 & 32.4 & 29.6 & 27.2 & 21.6 & 20.4 \\
Coefficient of variation (\%) & 33.5 & 34.5 & 34.7 & 34.6 & 34.7 & 34.9
\end{tabular}

Notes. *Not including the Republic of Crimea and Sevastopol.

The lowest rates (ten or less per 1,000 women of reproductive age) of registered abortions are in a number of republics in the North Caucasus, the Republic of Kalmykia and Moscow. The highest rates (over 30 per 1,000 women) in 2019, apart from the Jewish Autonomous Region, are in Yakutia, the Orenburg Region, the Sakhalin Region, Tuva, the Nenets Autonomous Region and the Republic of Altai. The Magadan, Irkutsk and Sverdlovsk regions are also among the top ten anti-leaders.

However, there is relatively little variation in the prevalence of spontaneous abortion; the coefficient of variation, based on the number of miscarriages per 1,000 women of reproductive age, is $21.4 \%$ (2019). The miscarriage rate ranges from 3.9 per 1,000 women aged $15-49$ in the Tambov and Tula regions to 10 per 1,000 in the Irkutsk and Magadan regions, with a Russian average of 6.7 per 1,000 (2019).

An estimate cited by the WHO suggests that an average of 10 to $15 \%$ of clinical pregnancies end in miscarriage ${ }^{8}$. Only one Russian region has exceeded the maximum limit of $15 \%$ in 2019 - the Ulyanovsk Region, while 17 regions have a share of less than 10\%, with the Russian average being $11 \%{ }^{9}$. The question of how the regions differentiate in terms of miscarriage rates needs to be specifically investigated. Presumably, in addition to women's health status, fertility rates play a role, since the higher the number of pregnancies, the higher the risk of pregnancy loss. Indeed, the Spearman's rank correlation coefficient $(r=0.461)$ shows a moderate relationship between the relative number of spontaneous abortions and the specific fertility rate, while no such relationship was found between the relative number of medical legal abortions and fertility. Territorial heterogeneity in the rate of induced abortions (without miscarriages but including abortions for medical and social reasons and unspecified abortions) is significantly higher than in the overall rate of pregnancy termination. It should be noted that in some regions the number of registered induced abortions is so low that these regions can be excluded from the analysis. In the Republic of Ingushetia, for example, 26 induced abortions were registered in 2018 and 36 in 2019. Less than 300 induced abortions a year are registered in the Nenets and Chukotka Autonomous Districts, as well as in Kalmykia. In Chechnya, Dagestan and Kabardino-Balkaria, the specific induced abortion rate (per 1,000 women of reproductive age) is three or lower - such low rates are not found in any country with liberal abortion laws; notably, Chechnya has one of the highest rates of miscarriage. Moscow (2.7 per 1,000 in 2019) joins this group of regions with a record low rate of induced abortions; such a low rate casts doubt on the completeness of abortion records in the capital. A second reason for caution is the questionable quality of population data for the North Caucasus and Moscow (used as a denominator in calculating the coefficients) [Mkrtchyan, 2019; Andreev, 2012].

Even without these regions, however, there is a wide variation in the rates of induced abortions: from 4.6 per 1,000 women in Moscow Region to 26.0 in Yakutia and 30.1 per 1,000

\footnotetext{
${ }^{8}$ Why We Need to Talk about Losing a Baby // World Health Organization. URL: https://www.who.int/ news-room/spotlight/why-we-need-to-talk-about-losing-a-baby (accessed on 20/04/2021).

${ }^{9}$ The number of pregnancies was estimated as the sum of the number of births (including stillbirths) and the number of pregnancy terminations.
} 
in the Jewish Autonomous Region (2019); the coefficient of variation is $41.5 \%$. A group with a low rate of induced abortions (less than 10 per 1,000) includes 24 of 77 Russian regions, while 16 regions form a group with a relatively high rate of induced abortions - more than 20 per 1,000 , with an average of 14.2 per 1,000 for 77 regions (see Table 3 ). The decline in abortions in the latter group has a lag of about a decade compared to the middle group.

Across Russia as a whole, about half of women of reproductive age (18 million out of 35 million) live in regions with low rates of induced abortions and three times less $-16 \%$ (6 million) - in regions with high rates of induced abortions. About a third of Russian women live in areas with an average score.

Discussion and conclusions. Accounting for pregnancy terminations in organisations of the Ministry of Health of Russia and in medical organisations not subordinate to the Ministry of Health is based on different forms of federal statistical observation. Until recently, the Ministry of Health's records remained much more detailed, but did not cover all abortions performed in the country. The most significant changes in the statistical forms have occurred since 2010, among which we should mention: the shortening of the gestational age at which abortion is performed (since 2012), the widening of the definition of spontaneous abortion (since 2012), and the almost complete elimination of the age distribution (since 2016). In 2016-2017, the published total number of abortions included all pregnancies with an abortion outcome (including e.g. ectopic pregnancies), resulting in a lack of comparability with other years. However, as of 2018, the content of the statistical forms for the organisations of the Ministry of Health and for organisations outside the Ministry of Health has changed again, and this was an important step forward in improving state statistics on abortion. The revision of observation

Table 3

Number of induced abortions per 1,000 women aged 15-49 years in Russian regions, 2019

\begin{tabular}{|c|c|}
\hline $\begin{array}{l}\text { Number of induced } \\
\text { abortions per } \\
1,000 \text { women aged } \\
15-49 \text { women aged } \\
15-49 \text { years }\end{array}$ & Regions* \\
\hline Less than 10 & $\begin{array}{l}\text { Moscow Region, Karachay-Cherkessia Republic, Rostov Region, Belgorod } \\
\text { Region, Republic of North Ossetia-Alania, Krasnodar Territory, Saint } \\
\text { Petersburg, Volgograd Region, Republic of Adygea, Republic of Mordovia, } \\
\text { Ryazan Region, Samara Region, Voronezh Region, Tula Region, Astrakhan } \\
\text { Region, Ulyanovsk Region, Yaroslavl Region, Stavropol Territory, Republic of } \\
\text { Crimea, Ivanovo Region, Lipetsk Region, Republic of Bashkortostan, Kaluga } \\
\text { Region, Omsk Region }\end{array}$ \\
\hline 10-20 & $\begin{array}{l}\text { Sevastopol, Saratov Region, Penza Region, Leningrad Region, Tver Region, } \\
\text { Khanty-Mansiysk Autonomous District - Ugra, Republic of Tatarstan, Murmansk } \\
\text { Region, Nizhny Novgorod Region, Tambov Region, Primorsky Territory, Altay } \\
\text { Region, Kursk Region, Smolensk Region, Vladimir Region, Novgorod Region, } \\
\text { Orel Region, Yamalo-Nenets Autonomous District, Kostroma Region, Republic } \\
\text { of Khakassia, Republic of Karelia, Chelyabinsk Region, Udmurt Republic, } \\
\text { Kaliningrad Region, Bryansk Region, Chuvash Republic, Kamchatka Region, } \\
\text { Amur Region, Republic of Buryatia, Vologda Region, Republic of Komi, } \\
\text { Khabarovsk Region, Kirov Region, Arkhangelsk Region (without Nenets } \\
\text { Autonomous District), Tomsk Region, Magadan Region, Irkutsk Region }\end{array}$ \\
\hline 20 and above & $\begin{array}{l}\text { Tyumen Region (without autonomous districts), Kemerovo Region, Zabaykalsky } \\
\text { Territory, Republic of Mari El, Perm Territory, Krasnoyarsk Territory, Sverdlovsk } \\
\text { Region, Pskov Region, Kurgan Region, Novosibirsk Region, Republic of Tyva, } \\
\text { Sakhalin Region, Republic of Altai, Orenburg Region, Republic of Sakha } \\
\text { (Yakutia), Jewish Autonomous Region }\end{array}$ \\
\hline
\end{tabular}

Note. * Excluded from analysis: Republic of Dagestan, Republic of Ingushetia, Kabardino-Balkar Republic, Chechen Republic, Nenets and Chukotka Autonomous Districts, Republic of Kalmykia, Moscow. 
forms for all types of healthcare organisations has become almost identical, opening up new analytical possibilities. However, only a fraction of the information collected is published.

In 2020, a section on "Pre-abortion counselling results" was added to the registration form to include the number of women who have received special counselling and the number of women who have refused abortions and have been registered for prenatal care. In our view, the proposed statistics are poorly verifiable; compulsory counselling aimed at discouraging abortion pushes women out of the realm of free medicine into the realm of paid services and is fertile ground for corruption to flourish.

The lack of official statistics remains the absence of important socio-demographic characteristics of women who terminate pregnancy (age, marital status, level of education, etc.). It may make sense for Rosstat to outsource this activity, as in France, where similar statistics are developed by scientific organisations.

Based on state statistics, it can be concluded that the problem of abortion as a medical and demographic problem in contemporary Russia has lost its urgency. Abortion rates have declined several times in the post-Soviet years. There is a convergence in the total number of pregnancies and the number of births, indicating an increase in the effectiveness of birth control. The favourable trend has led to a change in Russia's position in the ranking of developed countries with abortion statistics - our country has lost its status as the absolute leader. The decline in abortions can be expected to slow down in the near future due to the substantial exhaustion of reserves for this reduction.

However, the proportion of spontaneous abortions or miscarriages that do not depend on the will of the woman is increasing in Russia; it exceeded 37\% in 2019. Miscarriages mainly represent the loss of desired pregnancies and their prevention is important for both the family and the demographic situation. In 2019 , one in five $(21.6 \%)$ induced abortions in the country were performed in a private clinic. In non-governmental clinics, the safest method of terminating a pregnancy, medication abortion, is much more widely used. Perhaps it is women's preference for the modern medication abortion method that is leading to an increase in visits to private healthcare organisations. Improving the quality of services and promoting modern abortion technologies in public health facilities is a way of improving women's reproductive health.

The analysis also shows that the Russian average masks significant regional differences and they are greater than in than the birth rate. About a third of Russian regions have low rates of induced abortion, comparable to the best-off countries in Europe [Singh et al., 2018: 11]; one fifth of regions have relatively high rates, 1.5-2 times the national average. In other words, in parts of the regions, mainly in the north and east, the problem of abortion is still far from being resolved and requires close attention. The main reason for the decline in abortion rates has been the spread of modern family planning - Russians have begun to use reliable contraceptive methods more often [Vishnevsky et al., 2017]. Unfortunately, statistics on contraceptive use are of inferior quality to those on termination of pregnancy, and sample surveys on this topic are very rare. But it is safe to say that over the past decades, abortion has been transformed from the primary means of birth control in Russia into a "firefighting" measure, resorted to in cases of contraceptive failure.

\section{REFERENCES}

Avdeev A. (2011) Induced Abortion and Contraception in the 1990s - 2000s in the Mirror of Public and Private Statistics. In: Troitskaja I., Avdeev A. (eds) Fertility and Family Planning in Russia: History and Prospects. Moscow: TEIS: 9-36. (In Russ.)

Andreev E.M. (2012) On Accuracy of Russia Population Censuses Results and Level of Confidence in Different Sources of Information. Voprosy Statistiki. No. 11: 21-35. (In Russ.)

Avdeev A., Blum A., Troitskaja I. (1995) The History of Abortion Statistics in Russia and the USSR from 1900 to 1991. Population: An English Selection. No. 7: 39-66.

David H.P., Popov A.A. (1999) Russian Federation and USSR Successor States. In: David H.P., Skilogianis J. (eds) From Abortion to Contraception: A Resource to Public Policies and Reproductive Behavior 
in Central and Eastern Europe from 1917 to the Present. Westport, CT; London: Greenwood Press: 223-258.

Denisov B., Sakevich V. (2014) Abortion in Post-Soviet Russia: Is There any Reason for Optimism? Demograficheskoe obozrenie [Demographic Review]. Vol. 1. No. 5: 50-68. DOI: 10.17323/ demreview. v1i5.3172.

Mkrtchyan N. (2019) Migration in the North Caucasus and the Accuracy of Statistics. Zhurnal issledovaniy sotsialnoy politiki [The Journal of Social Policy Studies]. Vol. 17. No. 1: 7-22. DOI: 10.17323/727-06342019-17-1-7-22. (In Russ.)

Ryazantsev S.V., Rostovskaya T.K., Sigareva E.P., Sivoplyasova S. Yu. (2019) Abortions and Abortive Behavior in the Context of Searching for Demographic Development. Ekologiya cheloveka [Human Ecology]. No. 7: 17-23. DOI: 10.33396/1728-0869-2019-7-17-23. (In Russ.)

Singh S., Remez L., Sedgh G., Kwok L., Onda T. (2018) Abortion Worldwide 2017: Uneven Progress and Unequal Access. U.S.: Guttmacher Institute. URL: https:// worldwide-2017 (accessed 21.04.21).

Starodubov V.I., Sukhanova L.P. (2012) Reproductive Problems of Demographic Development in Russia. Moscow: Menedzher zdravoohraneniya. (In Russ.)

Sukhanova L.P. (2013) Statistical Information on the State of the Problem of Abortion and Infertility in the Russian Federation. Moscow: FGBU TSNIIOIZ. (In Russ.)

Vishnevsky A.G. (ed.) (2006) Demographic Modernization of Russia, 1900-2000. Moscow: Novoe izdatel'stvo. (In Russ.)

Vishnevsky A., Denisov B., Sakevich V. (2017) The Contraceptive Revolution in Russia. Demografitcheskoe obozrenie [Demographic Review]. Vol. 4. No. 5: 86-108. DOI: 10.17323/demreview.v4i5.8570.

Zhukov V.I. (2018) Legislation on Abortion: World Trends and National Interests. Sotsiologicheskie issledovaniya [Sociological Studies]. No. 3: 113-123. DOI: 10.7868/S0132162518030121. (In Russ.) 